\title{
Pengaruh Kombinasi Diet Tinggi Serat dan Senam Aerobik terhadap Penurunan Berat Badan
}

\author{
Taufik Maryusman ${ }^{1}$, A'immatul Fauziyah ${ }^{2}$, Iin Fatmawati ${ }^{3}$, Nur Indah Firdausa ${ }^{4}$, Siti \\ Imtihanah ${ }^{5}$ \\ 1,2,3,4,5 Program Studi S1 Ilmu Gizi, Fakultas Ilmu Kesehatan, Universitas Pembangunan Nasional "Veteran" \\ Jakarta \\ Jl. RS Fatmawati Pondok Labu Jakarta Selatan, 12450 \\ Email: pembelajartaufik@gmail.com
}

\begin{abstract}
ABSTRAK
Berat badan berlebih saat ini banyak ditakuti oleh orang yang ingin hidup sehat dan tampil menarik. Selain itu, masalah kesehatan sering muncul dikarenakan berat badan berlebih. Penanganan yang efisien salah satunya dengan cara kombinasi diet dan olahraga. Olahraga yang efektif adalah dengan olahraga secara aerobik, diantaranya senam aerobik. Tujuan penelitian ini adalah untuk mengetahui efektivitas kombinasi diet tinggi serat dan senam aerobik dalam menurunkan berat badan. Penelitian ini merupakan penelitian eksperimen semu (quasi experiment) dengan rancangan randomized pre-post test control group design. Besar sampel 22 orang yang sebagian besar berusia lanjut. Sampel dibagi menjadi dua kelompok yaitu perlakuan dan kelompok kontrol. Kelompok perlakuan diberikan diet tinggi serat dan senam aerobik dan kelompok kontrol hanya diberikan senam aerobik. Diet tinggi serat diberikan penambahan buah yang mengandung tinggi serat berupa jambu klutuk dan apel merah per harinya. Untuk senam aerobik diberikan $3 \mathrm{kali} /$ minggu dengan lama senam 30 menit. Pengukuran berat badan dilakukan sebelum dan sesudah 2 minggu perlakuan. Rerata penurunan berat badan pada kelompok perlakuan sebesar $1.1 \pm 0.005 \mathrm{~kg}$ dan kelompok kontrol sebesar $0.41 \pm 0.07$. Hasil analisis statistik menunjukkan bahwa ada perbedaan berat badan yang bermakna $(p<0.05)$ antara sebelum dan sesudah perlakuan dan juga pada kelompok kontrol $(\mathrm{p}<0.05)$. Namun, tidak ada perbedaan penurunan berat badan yang bermakna $(\mathrm{p}<0.05)$ antara kelompok perlakuan dan kontrol. Dengan demikian kombinasi diet tinggi serat dan senam aerobik memiliki pengaruh terhadap penurunan berat badan. Diharapkan tenaga kesehatan selain menyelenggarakan senam bersama masyarakat, juga memberikan edukasi tentang pentingnya mengkonsumsi sayuran dan buah yang mengandung tinggi serat.
\end{abstract}

Kata Kunci: diet tinggi serat, senam aerobik, berat badan

\section{The Influence of High Fiber Diet and Aerobic Gym Combination on Weight Loss}

\begin{abstract}
Nowadays overweight was feared by people who want to live health and look attractive. In addition, problems in healthy often appear because overweight. Efficient handling is a way with a combination of diet and exercise. Effective exercise is by aerobic exercise, such as aerobic exercise. The purpose of this research was to know the effectiveness a combination of high fiber diet and aerobic exercise on weight loss. This research is a quasi experiment with randomized pre-post test control group design. The sample are 22 people who mostly elderly. The sample was divided into two groups namely treatment group and control group. The treatment group was given a high-fiber diet and aerobic
\end{abstract}


exercise. The control group was given only aerobic exercise. High fiber diet is given the fruit containing high fiber such as guava and red apples each of day. Aerobic exercise was given 3 times in a week. It durations 30 minutes. Weight measurement was done before treatment and also it was done after 2 weeks treatment. The mean of weight loss in treatment group was $1.1 \pm 0.005 \mathrm{~kg}$ and control group was $0.41 \pm 0.07$. The result of statistical analysis showed that there was significant weight difference $(\mathrm{p}$ $<0.05)$ between before treatment and after treatment. Moreover in control group ( $\mathrm{p}<0.05)$. However, there was no significant difference in weight loss $(\mathrm{p}<0.05)$ between the treatment and control groups. Thus a combination of high-fiber diet and aerobic exercise give an influence towards weight loss.

Keywords: high fiber diet, aerobic exercise, body weight

\section{Pendahuluan}

Meningkatnya prevalensi obesitas merupakan masalah kesehatan utama diseluruh dunia. Saat ini terdapat bukti bahwa prevalensi kelebihan berat badan meningkat sangat tajam diseluruh dunia, yang mencapai tingkatan yang mengkhawatirkan seiring dengan kebiasaan, cara mengkonsumsi, dan gaya hidup berubah ${ }^{1}$. Menurut WHO, sekitar 2,8 juta orang dewasa meninggal setiap tahun terkait dengan kelebihan berat badan dan obesitas. Prevalensi populasi orang dewasa lebih dari $10 \%$ di dunia mengalami obesitas dan sebanyak 300 juta adalah wanita ${ }^{2}$. Di Indonesia, angka obesitas terus meningkat. Berdasarkan Riskesdas, prevalensi obesitas pada laki-laki dewasa terjadi peningkatan dari 13,9\% pada tahun 2007 menjadi $19,7 \%$ pada tahun 2013. Sedangkan pada wanita dewasa juga terjadi kenaikan yang sangat ekstrim mencapai $32,9 \%$ pada tahun 2013 dari $14.8 \%$ pada tahun $2007^{3}$.

Perubahan pola konsumsi pangan di Indonesia menyebabkan berkurangnya konsumsi sayuran dan buah. Hal ini juga diikuti oleh terjadinya perubahan pola penyakit penyebab mortalitas di masyarakat. Wilayah perkotaan yang sebagian masyarakatnya menggunakan kendaraan dan memiliki kesibukan tinggi diluar rumah cenderung mengkonsumsi makanan siap saji dan terjadi pergeseran pola makan dari tinggi karbohidrat, tinggi serat dan rendah lemak ke pola konsumsi rendah karbohidrat dan rendah serat, tinggi lemak dan tinggi protein. Hal inilah yang menyebabkan tingginya kasus penyakit kardiovaskuler yang berhubungan dengan sindroma metabolik dan penyakit degeneratif lainnya di Indonesia ${ }^{4}$.

Pola makan rendah serat menjadi salah satu resiko yang dapat menyebabkan terjadinya obesitas dan DCS (Disease of Circulatory System). Seorang yang mengonsumsi makanan berserat lebih dari 35 gram/hari memiliki resiko mengalami penyakit jantung 1/3 lebih rendah dari orang yang hanya mengonsumsi serat sebanyak 15 gram $/$ hari $^{5}$. Penerapan diet yang tinggi serat dapat menurunkan berat badan, bila mengonsumsi serat larut air (pektin, gums, musilago, dan sejumlah hemiselulosa $)^{6}$.

Olahraga merupakan usaha yang paling baik untuk menurunkan berat badan bila dibanding dengan diet saja. Olahraga dalam hal ini adalah latihan dengan intensitas rendah dalam jangka waktu lama. Tubuh kita memerlukan sejumlah energi tertentu untuk melanjutkan fungsi yang diperlukan demi kelangsungan hidup. Jika kita berolahraga, tubuh kita bekerja lebih keras dan memerlukan 
Taufik Maryusman, A’immatul Fauziyah, Iin Fatmawati, Nur Indah Firdausa, Siti Imtihanah, Pengaruh Kombinasi Diet Tinggi Serat dan Senam Aerobik terhadap Penurunan Berat Badan DOI : $10.24853 /$ jkk.14.1.56-62

kalori lebih banyak. Bahkan setelah kita berhenti berolahragapun tubuh kita terus membakar kalori selama beberapa jam. Dengan membakar lebih banyak kalori, dapat mengurangi lemak dan mengubah komposisi tubuh yang lebih sehat. Menurunkan lemak tubuh membuat tubuh kita kelihatan lebih baik dan menurunkan resiko obesitas. Hasil penelitian yang dilakukan pada mahasiswi gizi Poltekkes Denpasar, senam ayo bangkit memiliki efektifitas dalam menurunkan berat badan sebanyak $5.6 \%$ dari berat badan semula atau setara dengan $3.4 \mathrm{~kg}$ selama 6 minggu intervensi ${ }^{7}$.

Pola makan sehat seperti tinggi serat disertai dengan senam aerobik merupakan terapi dalam pengaturan berat badan dan juga dapat mengurangi kejadian penyakit kardiovaskuler. Penelitian ini dilakukan untuk menilai efektifitas diet tinggi serat disertai dengan senam aerobik terhadap penurunan berat badan.

\section{Metode}

Penelitian ini merupakan penelitian eksperimen semu (quasi experiment) dengan rancangan randomized pre-post test control group design. Memperhitungkan kemungkinan sampel drop out, cadangan sampel disiapkan sebesar 10 persen dari jumlah sampel minimal. Sampel yang diperlukan untuk setiap kelompok sebanyak 11 orang sehingga jumlah untuk 2 kelompok adalah 22 orang.

Rancangan ini melibatkan 2 kelompok yaitu kelompok kontrol dan kelompok perlakuan. Kelompok perlakuan dan kelompok kontrol diukur terlebih dahulu berat badannya.
Untuk kelompok perlakuan, diberikan diet tinggi serat dan senam aerobik, sedangkan untuk kelompok kontrol hanya diberikan senam aerobik. Pemberian diet tinggi serat pada kelompok perlakuan dengan cara memberikan penambahan buah yang mengandung tinggi serat berupa jambu klutuk dan apel merah kepada responden untuk menambahkan asupan serat responden per harinya. Untuk senam aerobik diberikan $3 \mathrm{kali} / 1$ minggu dengan lama senam 30 menit pada masing-masing kelompok yang dipandu oleh seorang instruktur senam aerobik. Intervensi diberikan selama 2 minggu, kemudian dilakukan pengukuran kembali berat badannya baik pada kelompok perlakuan maupun kelompok kontrol.

Penelitian ini dilakukan di Puskesmas Kecamatan Ciputat, Tangerang Selatan. Penelitian ini menggunakan cara pengambilan sampel non-probability sampling dengan menggunakan Judgemental Sampling. Data yang telah dikumpulkan diolah secara statistik deskriptif dan inferensia yang dilakukan meliputi uji normalitas Kolmogorov-Smirnov. Uji yang digunakan adalah paired t test untuk mengetahui perbedaan penurunan berat badan pada masing-masing kelompok dan perbedaan rerata berat badan sebelum dan sesudah perlakuan pada kedua kelompok.

Penelitian ini telah mendapatkan persetujuan etik dari Komisi Etik Penelitian Kesehatan (KEPK) UPN "Veteran" Jakarta yang dibuktikan dengan surat Persetujuan Etik Nomor: B/785/XI/2016/KEPK. 


\section{Hasil}

Karakteristik subjek penelitian pada kedua kelompok sebelum perlakuan seperti pada tabel 1. Sebagian besar responden berjenis kelamin perempuan sebesar $81.81 \%$ pada kelompok perlakuan dan $90 \%$ pada kelompok kontrol dan berusia dewasa (>25 Tahun) $81.8 \%$ pada kelompok perlakuan dengan rerata usia 61 tahun dan $45.5 \%$ pada kelompok kontrol. Responden pada kelompok perlakuan umumnya memiliki pendidikan menengah $36.4 \%$ dan pada kelompok kontrol 54.5\%. Pendapatan sebagian besar responden rendah $(<5.000 .000) 72.7 \%$ pada kelompok perlakuan dan 90,9\% pada kelompok kontrol.

Tabel 1. Deskripsi Karakteristik Responden di Awal Penelitian

\begin{tabular}{|c|c|c|c|c|}
\hline \multirow[t]{2}{*}{ Karakteristik Responden } & \multicolumn{2}{|c|}{$\begin{array}{l}\text { Kelompok } \\
\text { Perlakuan }\end{array}$} & \multicolumn{2}{|c|}{$\begin{array}{c}\text { Kelompok } \\
\text { kontrol }\end{array}$} \\
\hline & Jumlah & $\%$ & Jumlah & $\%$ \\
\hline \multicolumn{5}{|l|}{ Jenis Kelamin } \\
\hline - Laki-Laki & 2 & 18.18 & 1 & 9.1 \\
\hline - Perempuan & 9 & 81.81 & 10 & 90.0 \\
\hline \multicolumn{5}{|l|}{ Usia } \\
\hline $\begin{array}{l}\text { - Usia Dewasa } \\
\text { (>25 Tahun) }\end{array}$ & 9 & 81.8 & 5 & 45.5 \\
\hline $\begin{array}{l}\text { - Usia Lanjut } \\
\text { (>65 Tahun) }\end{array}$ & 2 & 18.2 & 6 & 54.5 \\
\hline \multicolumn{5}{|l|}{ Pendidikan terakhir } \\
\hline - Tidak sekolah & 2 & 18.2 & 0 & 0 \\
\hline - Pendidikan Dasar & 3 & 27.3 & 4 & 36.4 \\
\hline - Pendidikan Menengah & 4 & 36.4 & 6 & 54.5 \\
\hline - Pendidikan Tinggi & 2 & 18.2 & 1 & 9.1 \\
\hline \multicolumn{5}{|l|}{ Pendapatan } \\
\hline $\begin{array}{l}\text { - Rendah } \\
(<5.000 .000)\end{array}$ & 8 & 72.7 & 10 & 90.9 \\
\hline $\begin{array}{l}\text { - Sedang } \\
\quad(5.000 .000-10.000 .000)\end{array}$ & 3 & 27.3 & 1 & 9.1 \\
\hline
\end{tabular}


Taufik Maryusman, A’immatul Fauziyah, Iin Fatmawati, Nur Indah Firdausa, Siti Imtihanah, Pengaruh Kombinasi Diet Tinggi Serat dan Senam Aerobik terhadap Penurunan Berat Badan DOI : $10.24853 /$ jkk.14.1.56-62

Tabel 2. Hasil Uji Beda Rerata Berat Badan Sebelum dan Setelah Perlakuan pada Kedua Kelompok

\begin{tabular}{|c|c|c|c|c|c|c|}
\hline \multirow{2}{*}{ Variabel } & \multicolumn{3}{|c|}{ Kelompok Perlakuan } & \multicolumn{3}{|c|}{ Kelompok Kontrol } \\
\hline & Min & Maks & Rerata \pm SD & Min & Maks & Rerata \pm SD \\
\hline \multicolumn{7}{|l|}{ Berat Badan } \\
\hline - Sebelum & 53 & 83.8 & $62.8 \pm 9.728$ & 50.5 & 76.1 & $63.45 \pm 8.77$ \\
\hline - Setelah & 51.3 & 81.8 & $61.7 \pm 9.732$ & 49.9 & 75.6 & $63.04 \pm 8.70$ \\
\hline Beda (kg) & & & $1.1 \pm 0.005$ & & & $0.41 \pm 0.07$ \\
\hline$p$ value & & & 0.001 & & & 0.004 \\
\hline
\end{tabular}

Tabel 3. Hasil Uji Beda Efek Perlakuan terhadap Penurunan Berat Badan

\begin{tabular}{ccccc}
\hline Kelompok & $\begin{array}{c}\mathbf{n} \\
(\text { Orang) }\end{array}$ & $\begin{array}{c}\text { Rerata } \\
(\mathbf{K g})\end{array}$ & SD & $\mathbf{p}$ \\
\hline Perlakuan & 11 & 1.13 & 0.22 & 0.06 \\
Kontrol & 11 & 0.58 & 0.16 & \\
\hline
\end{tabular}

Hasil uji pada Tabel 2 menunjukan rerata penurunan berat badan pada kelompok perlakuan sebesar $1.1 \pm 0.005 \mathrm{~kg}$ dan kelompok

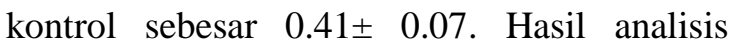
statistik menunjukkan bahwa ada perbedaan berat badan yang bermakna $(\mathrm{p}<0.05)$ antara sebelum dan sesudah perlakuan pemberian diet tinggi serat beserta senam aerobik dan juga pada kelompok kontrol $(\mathrm{p}<0.05)$. Hasil uji pada Tabel 3 menunjukan tidak ada perbedaan penurunan berat badan yang bermakna $(\mathrm{p}<0.05)$ antara kelompok perlakuan dan kontrol.

\section{Pembahasan}

Terjadinya penurunan berat badan pada kelompok perlakuan dan kontrol merupakan efek dari senam aerobik dikarenakan dalam latihan aerobik 20 menit pertama, tubuh akan menggunakan energi dari karbohidrat yang berasal dari makanan dan cadangan yang tersimpan di dalam hati. Setelah itu menit ke-30 latihan aerobik maka lemak akan dimetabolisme. Pembakaran cadangan lemak tubuh sebagai sumber energi akan menyebabkan penurunan lemak tubuh ${ }^{7}$. Kelompok yang hanya diberikan senam aerobik pada penelitian ini tidak jauh berbeda dengan penelitian dengan program olahraga penurunan berat badan khusus dengan waktu latihan lebih dari 2 bulan mengalami penurunan berat badan sebesar $0.63 \mathrm{~kg} \pm 0.55^{8}$.

Serat mempunyai kemampuan menahan air dan dapat membentuk cairan kental dalam saluran pencernaan. Sehingga makanan kaya akan serat, waktu dicerna lebih lama dalam lambung, kemudian serat akan menarik air dan memberi rasa kenyang lebih lama sehingga mencegah untuk mengkonsumsi makanan lebih banyak. Makanan dengan kandungan serat kasar yang tinggi biasanya mengandung kalori rendah, kadar gula dan 
lemak rendah yang dapat membantu mengurangi bertambahnya berat badan ${ }^{4}$. Penelitian lain menyatakan bahwa dengan konsumsi tinggi serat dapat menurunkan rerata asupan kalori dari 1646 Kkal menjadi 1387 $\mathrm{Kkal}^{9}$. Kombinasi diet tinggi serat dengan senam aerobik memberikan efek penurunan berat badan yang lebih tinggi yaitu $1.1 \mathrm{~kg}$ dibandingkan dengan hanya senam aerobik sebesar $0.41 \mathrm{~kg}$ walaupun tidak bermakna secara statistik $(p>0.05)$. Kombinasi diet disertai olahrga efektif dapat mengurangi jaringan adiposa dan menghemat jaringan tanpa lemak dan otot ${ }^{10}$. Selain itu, diet dan latihan aerobik juga dapat meningkatkan kadar HDL darah yang memiliki peran dalam meningkatkan metabolisme lemak sehingga diet tinggi serat memiliki manfaat positif untuk menghilangkan penyebab kelebihan berat badan $^{11}$.

\section{Kesimpulan dan Saran}

Intervensi diet tinggi serat dan senam aerobik selama dua minggu dapat menurunkan berat badan secara bermakna $(\mathrm{p}=0,000)$. Penurunan berat badan yang signifikan terjadi pada kelompok perlakuan dibandingkan dengan kelompok kontrol. Disarankan untuk menambah waktu intervensi dan jumlah sampel untuk meningkatkan keefektifan uji klinis.

\section{Daftar Pustaka}

1. Roemling C, Qaim M. Obesity trends and determinants in Indonesia. Appetite. 2012;58(3):1005-13.
2. World Health Organization. Obesity and Overweight. Geneva; 2004.

3. Badan Penelitian dan Pengembangan Kesehatan Republik Indonesia. Riset Kesehatan Dasar (RISKESDAS) 2013. Badan Penelitian dan Pengembangan Kesehatan Kementerian Kesehatan RI. 2013.

4. Santoso MP. Serat Pangan (Dietary Fiber) dan Manfaatnya bagi Kesehatan. Magistra. 2011;23(75).

5. Handajani A, Roosihermiatie B, Maryani H. Faktor-faktor yang Berhubungan dengan Pola Kematian Pada Penyakit Degeneratif di Indonesia. Bul Penelit Sist Kesehat. 2010;13:4253.

6. Fatmah. Gizi Usia Lanjut. Jakarta: Erlangga; 2010.

7. Dewantari NM. Efektivitas Senam Ayo Bangkit dan Diet Energi Rendah dalam Menurunkan Berat Badan. In: Prosiding Temu Ilmiah PERSAGI. 2009.

8. Sugiarti N, Noor Z. Pengaruh Program Olahraga Umum (Senam Aerobik) dan Khusus (Body Language dan Senam Aerobik) terhadap Penurunan Berat Badan. 2008;8(1):1-8.

9. Turner TF, Nance LM, Strickland WD, Malcolm RJ, Pechon S, O’Neil PM. Dietary adherence and satisfaction with a bean-based high-fiber weight loss diet: a pilot study. ISRN Obes [Internet]. 2013;2013:915415. Available from: http://www.pubmedcentral.nih.gov/arti clerender.fcgi $?$ artid $=3901975 \&$ tool $=p$ mcentrez\&rendertype $=\mathrm{abstract}$ 
Taufik Maryusman, A’immatul Fauziyah, Iin Fatmawati, Nur Indah Firdausa, Siti Imtihanah, Pengaruh Kombinasi Diet Tinggi Serat dan Senam Aerobik terhadap Penurunan Berat Badan

DOI : $10.24853 / \mathrm{jkk} \cdot 14.1 .56-62$

10. Sharkey BJ. Kebugaran dan Kesehatan.

Jakarta: PT. Rajagrafindo Persada;

2003.

11. Kelley GA, Kelley KS. Effects of diet, aerobic exercise, or both on non-HDL-C in adults: A meta-analysis of randomized controlled trials.

Cholesterol. 2012;2012(1):1-6. 